\title{
Pelatihan Instalasi Listrik Rumah Tangga Dan Elektronika Dasar Bagi Pemuda Di Desa Cilame Kecamatan Ngamprah Kabupaten Bandung Barat
}

\author{
Zul Fakhri, Sunubroto, Handoko Rusiana Iskandar, Ahmad Daelami \\ Jurusan Teknik Elektro, Universitas Jenderal Achmad Yani \\ Penulis korespondensi : zulfakhri18@gmail.com
}

\begin{abstract}
Abstrak: Desa Cilame adalah sebuah kawasan di Kecamatan Ngamprah Kabupaten Bandung Barat, Jawa Barat. Cilame merupakan desa terluas di Kecamatan Ngamprah dan dihuni penduduk sekitar 34.689 jiwa yang tergabung dalam 25 Rukun Warga (RW). Jumlah masyarakat yang tergolong pemuda usia produktif 15 tahun s/d 30 tahun sebanyak 6.533 jiwa. Dari jumlah tersebut, jumlah pemuda yang putus sekolah sebanyak 1.287 orang. Makalah ini menguraikan tentang kegiatan pengabdian kepada masyarakat dalam bentuk pelatihan instalasi listrik rumah tangga dan elektronika dasar untuk pemuda putus sekolah di desa Cilame. Pemberian pelatihan tersebut ditujukan agar pemuda putus sekolah dapat menggunakan hasil pengetahuan dan keterampilan untuk keperluan sendiri atau untuk membuka usaha dengan berwiraswasta. Program pelatihan dalam kegiatan pengabdian masyarakat ini terbagi menjadi beberapa bagian, yaitu pre-test, pembuatan modul pelatihan, diskusi interaktif, workshop, dan post test. Kegiatan pelatihan ini bertempat di Gedung Aula Desa Cilame Kecamatan Ngamprah, Kabupaten Bandung Barat dan diikuti oleh 12 peserta. Program pelatihan berjalan dengan baik dan lancar sesuai dengan rencana kegiatan yang telah disusun. Meskipun belum semua peserta menguasai dengan baik materi yang disampaikan, tetapi peserta antusias dalam mengikuti pelatihan yang diberikan dan terlibat aktif dalam sesi diskusi maupun praktik.
\end{abstract}

Kata kunci: keterampilan, pelatihan elektronika dasar, pelatihan instalasi listrik, pemuda putus sekolah, wirausaha.

\begin{abstract}
Cilame Village is an area in Ngamprah subdistrict, Bandung Barat Regency, Jawa Barat. Cilame is the largest village in Ngamprah subdistrict and is inhabited by a population of around 34,689 people who are members of 25 Community Associations (RW). The number of people classified as productive age is 6,533 people. Among them, the number of youth who dropped out of school was 1,287 people. This paper describes community service activities in the form of basic electrical and household electronics training for youths who have dropped out of school in the Cilame Village. The training is intended so that young school dropouts can use the results of knowledge and skills for their own needs or to be an entrepreneur. The training program in community service activities is divided into several sections, namely pre-test, developing training modules, interactive discussions, workshops, and post-tests. This training activity took place in the Hall of Cilame Village, Ngamprah District, West Bandung Regency and was attended by 12 participants. The training program runs well and smoothly in accordance with the planned activities that have been prepared. Participants were enthusiastic in participating in the training provided and were actively involved in the discussion and practice sessions.
\end{abstract}

Keywords: basic electronics training, basic household training, dropped out people, skills.

Volume 1, Nomor 1, Maret 2020 | 11

Pelatihan Instalasi Listrik Rumah Tangga Dan Elektronika Dasar Bagi Pemuda Di Desa Cilame Kecamatan Ngamprah Kabupaten Bandung Barat

Zul Fakhri, Sunubroto, Handoko Rusiana Iskandar, Ahmad Daelami

https://doi.org/10.26874/jakw.v1i1.10 


\section{Pendahuluan}

Desa Cilame adalah sebuah kawasan di Kecamatan Ngamprah Kabupaten Bandung Barat, Jawa Barat. Luas wilayah Desa Cilame adalah $480 \mathrm{~km}^{2}$ dengan ketinggian $680 \mathrm{~m}$ dari permukaan laut, sedangkan secara topografi wilayah Desa Cilame tergolong kategori wilayah berbukit dengan posisi permukaan tanah miring dari arah utara ke arah barat, iklim yang mempengaruhinya rata-rata mempunyai curah hujan antara 1500-2000 mm per tahun serta suhu rata-rata antara $18^{\circ} \mathrm{C}$ sampai $30^{\circ} \mathrm{C}$. Mata pencaharian penduduk sebagian besar bertani padi dan sayur mayur. Wilayah Desa Cilame sebagian besar terdiri dari hamparan lahan perkebunan dan pertanian yang luas, serta terlihat ada beberapa peternakan. Cilame merupakan desa terluas di Kecamatan Ngamprah dan dihuni penduduk sekitar 34.689 jiwa yang tergabung dalam 25 Rukun Warga (RW). Jumlah masyarakat yang tergolong pemuda usia produktif 15 tahun s/d 30 tahun sebanyak 6.533 jiwa. Dari jumlah tersebut, jumlah pemuda yang putus sekolah sebanyak 1.287 orang (Badan Pusat Statistik, 2018).

Berdasarkan latar belakang tersebut, upaya peningkatan pengetahuan dan keterampilan masyarakat Desa Cilame perlu dilakukan melalui suatu pelatihan agar para pemuda yang putus sekolah dapat menggunakan hasil pengetahuan dan keterampilan untuk keperluan sendiri atau untuk membuka usaha dengan berwiraswasta. Pemuda putus sekolah adalah salahsatu kelompok masyarakat yang mudah terkena pengaruh negatif dari luar sehingga harus diarahkan untuk mengikuti kegiatan yang bermanfaat (Suranti dkk., 2018). Beberapa kegiatan pelatihan yang dapat dilakukan untuk membekali pemuda putus sekolah, misalnya pelatihan montir motor (Hidayat dkk., 2018; Nasrullah \& Fatimah, 2017), keterampilan dalam bidang multimedia (Suranti dkk., 2018), keterampilan menjahit, pelatihan, fotografi, dan tata boga (Resyaningrum, 2019).

Salah satu pelatihan untuk meningkatkan keterampilan pemuda di Desa Cilame adalah pelatihan elektronika dasar dan pelatihan instalasi listrik rumah sederhana. Kegiatan pelatihan yang dilakukan bertujuan mendidik para pemuda peserta latih untuk meningkatkan pengetahuan dan keterampilan masyarakat Desa Cilame agar adaptif, kreatif, inovatif dan produktif serta mampu menciptakan lapangan kerja yang mampu bersaing di bidang elektronika dan mampu mensosialisasikan serta mampu merealisasikan standar kelistrikan instalasi listrik rumah sederhana. Karakter adaptif, kreatif, inovatif dan produktif diperlukan wirausaha kecil dan menengah agar tangguh dalam menjalankan usahanya (Hadiyati, 2011).

Volume 1, Nomor 1, Maret 2020 | 12

Pelatihan Instalasi Listrik Rumah Tangga Dan Elektronika Dasar Bagi Pemuda Di Desa Cilame Kecamatan Ngamprah Kabupaten Bandung Barat 
Dalam pelatihan tersebut, setiap peserta dibekali pengetahuan dan keterampilan dalam bidang elektronika dasar, seperti memahami jenis-jenis komponen elektronika, menggunakan alat ukur dan membuat rangkaian elektronika. Selain itu, mereka juga dibekali pengetahuan dan keterampilan dalam bidang instalasi listrik rumah, seperti memahami jenis, komponen dan simbol kelistrikan, memasang instalasi listrik rumah sederhana, dan mampu mencari kerusakan apabila terjadi gangguan pada instalasi listrik rumah. Setelah mengikuti kegiatan tersebut, para pemuda peserta latih Desa Cilame diharapkan memperoleh peningkatan pengetahuan dan keterampilan dalam bidang elektronika dasar dan instalasi listrik rumah sederhana serta diharapkan dapat menyebarluaskan pengetahuan dan keterampilan tentang elektronika dasar dan instalasi listrik rumah kepada masyarakat Desa Cilame. Selain itu, hasil pelatihan dapat dijadikan sebagai modal keterampilan untuk dapat membuka usaha sendiri dengan berwirausaha di bidang perbaikan alat elektronika dan pemasangan instalasi listrik.

\section{Metode}

\subsection{Program Pelatihan}

Program pelatihan dalam kegiatan pengabdian masyarakat ini terbagi menjadi beberapa bagian, yaitu pre-test, pembuatan modul pelatihan, diskusi interaktif, workshop, dan post test. Dalam bagian pre-test, peserta pelatihan diberi soal-soal teori penunjang pelatihan yang telah dipelajari sebelum pelatihan dimulai. Pertanyaan yang diberikan berupa materi yang akan disampaikan kepada seluruh peserta pelatihan, biasanya dilakukan pada saat pembukaan kegiatan pelatihan berlangsung. Dengan pretest, instruktur pelatihan akan menentukan penyampaian materi yang dilakukan.

Untuk membantu keefektifan target kegiatan, sebuah modul pelatihan disusun sebagai panduan bagi peserta dan instruktur dalam pelaksanaan pelatihan. Modul tersebut disusun agar dapat dipelajari secara mandiri oleh peserta kegiatan, karena didalamnya telah dilengkapi petunjuk-petunjuk yang memungkinkan peserta pelatihan dapat mempelajarinya saat pelatihan atau sesudahnya. Modul yang disusun terdiri dari 3 (tiga) modul yaitu pengenalan teori dasar komponen elektronika, pembuatan penyearah dan catu daya, serta instalasi listrik di rumah. Uraian dalam modul tersebut mencakup pengenalan komponen elektronika, pengenalan alat ukur, pengenalan simbol-simbol kelistrikan, membuat layout PCB rangkaian catu daya. pembuatan gambar instalasi listrik rumah sederhana, serta 
melakukan pengujian perangkat instalasi yang telah dibuat.

Kegiatan lainnya berupa diskusi interaktif dan workshop. Diskusi interaktif dilakukan untuk memperkuat pemahaman materi pelatihan dan melatih keberanian dalam mengemukakan pendapat. Sementara itu, kegiatan workshop berisi pertukaran pengetahuan dan pengalaman antar peserta yang mempunyai keahlian atau profesi yang sama, guna meningkatkan pengetahuan atau memecahkan suatu masalah selama kegiatan pelatihan berlangsung khususnya keahlian elektronika dasar maupun instalasi listrik rumah sesuai dengan aturan PUIL (Peraturan Umum Instalasi Listrik). Sebagai bentuk evaluasi terhadap pemahaman materi pelatihan, post-test diberikan kepada para peserta dalam bentuk pertanyaan yang diberikan setelah kegiatan pemberian materi yang telah disampaikan.

\subsection{Pelaksanaan Program}

Dalam kegiatan pengadian masyarakat ini, peserta pelatihan adalah para pemuda yang dipilih dan ditugaskan oleh Ketua RW masing-masing. Ketentuan selengkapnya dari peserta kegiatan pelatihan ini adalah sebagai berikut:

a) Pemuda Desa Cilame Kecamatan Ngamprah Kabupaten Bandung Barat sebanyak 12 orang.

b) Belum pernah mengikuti pelatihan sejenis dan sanggup serta bersedia mengikuti semua kegiatan pelatihan.

c) Memiliki surat tugas dari ketua RW masing-masing.

d) Tiap peserta menggunakan 1 (satu) set peralatan pelatihan yang sudah disediakan

e) Setelah selesai mengikuti semua rangkaian kegiatan pelatihan dan workshop, peserta akan diberikan sertifikat dengan ketentuan terus mengikuti acara pelatihan sampai akhir.

Kegiatan pelatihan dalam rangka pengabdian kepada masyarakat ini bertempat di Gedung Aula Desa Cilame Kecamatan Ngamprah Kabupaten Bandung Barat. Tempat tersebut cukup representatif untuk melaksanakan kegiatan pelatihan dengan peserta yang ditentukan yang berasal dari wilayah tersebut.

\section{Hasil dan Diskusi}

Kegiatan pengabdian kepada masyarakat yang dilaksanakan dengan acara tatap muka dan praktek, pengembangan media pembelajaran berjalan dengan baik dan lancar. Pertemuan

Volume 1, Nomor 1, Maret 2020| 14

Pelatihan Instalasi Listrik Rumah Tangga Dan Elektronika Dasar Bagi Pemuda Di Desa Cilame Kecamatan Ngamprah Kabupaten Bandung Barat Zul Fakhri, Sunubroto, Handoko Rusiana Iskandar, Ahmad Daelami https://doi.org/10.26874/jakw.v1i1.10 
tatap muka dengan metode ceramah dan demonstrasi, dilanjutkan latihan atau praktek untuk membuat sesuai dengan langkah kegiatan, mulai dari pengenalan teori dasar komponen elektronika hingga pengenalan komponen dan simbol-simbol kelistrikan, kemudian pembuatan rangkaian elektronika dasar penyearah, membuat layout PCB rangkaian catu daya, pembuatan gambar instalasi listrik rumah sederhana dan membuat perangkat catu daya dan pemasangan instalasi listrik rumah, serta melakukan pengujian perangkat instalasi yang telah dibuat.

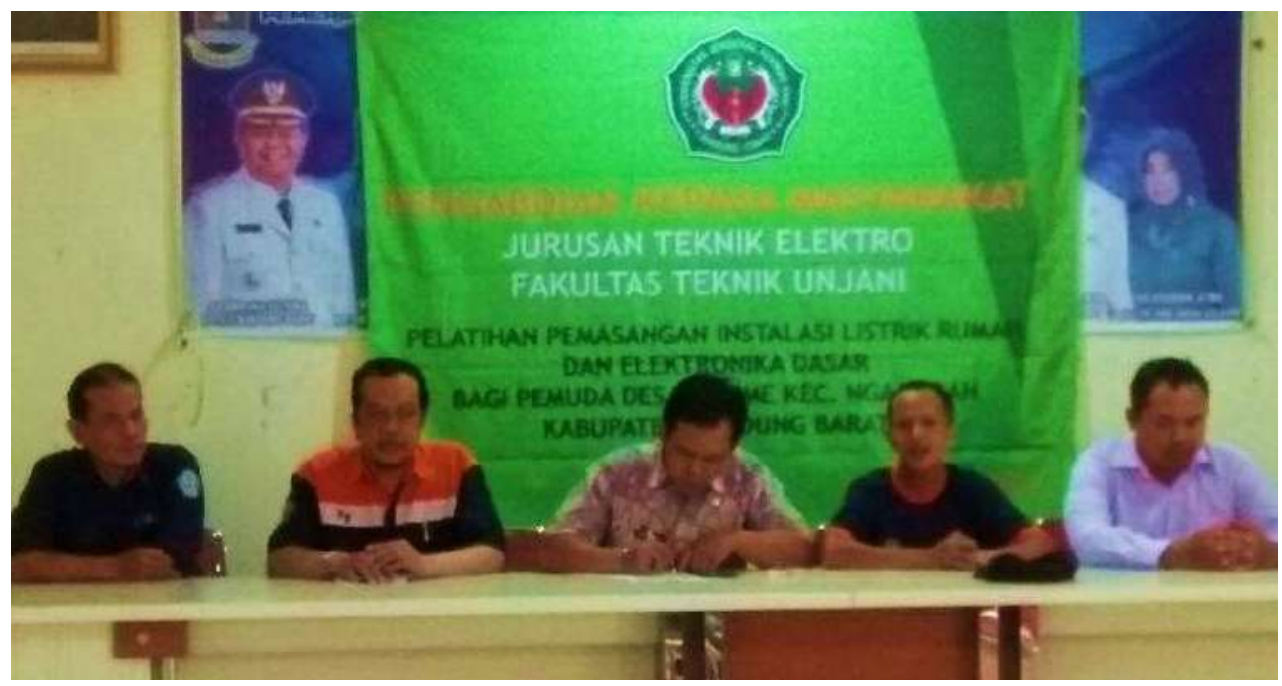

Gambar 1. Pembukaan kegiatan didampingi pejabat setempat

Kegiatan pelatihan ini dilaksanakan pada tanggal 7 Februari 2019 dari pukul 07.30-17.00 WIB. Peserta kegiatan berjumlah 12 pemuda Desa Cilame Kecamatan Ngamprah Kabupaten Bandung Barat dan lokasi penyelenggaraan pelatihan di Geduang Aula Desa Cilame Kecamatan Ngamprah, Kabupaten Bandung Barat. Pelatihan dibuka secara resmi oleh pejabat setempat seperti ditunjukkan pada Gambar 1.

Materi yang disampaikan terdiri dari konsep dasar komponen elektronika, simbol-simbol kelistrikan, dan denah instalasi listrik rumah sederhana seperti diperlihatkan pada Gambar 2 . Metode pelatihan dilaksanakan dengan pemberian materi oleh instruktur dan praktik langsung dibimbing oleh instruktur lainnya seperti ditunjukkan dalam Gambar 3-4. Di sesi akhir pelatihan, post-test diberikan berupa tugas merangkai instalasi listrik sederhana berdasarkan gambar yang diberikan oleh instruktur. Salahsatu kelompok yang berhasil menyelesaikan tugasnya ditunjukkan pada Gambar 5. 


\begin{tabular}{|c|c|c|}
\hline Sumakomponen & Gambir & $\sin \infty \infty^{\circ}$ \\
\hline $\begin{array}{l}\text { Diloden } \\
\text { neoveseren }\end{array}$ & $=$ & \\
\hline $\begin{array}{l}\text { Droda } \\
\text { Zeneet }\end{array}$ & -2 & \\
\hline Lo & 2. & \\
\hline 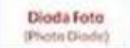 & & \\
\hline sor & $-60_{0}$ & \\
\hline  & & \\
\hline
\end{tabular}

(a)



(b)

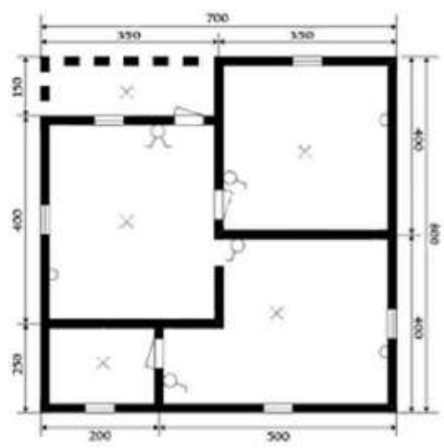

(c)

Gambar 2. Konsep yang diberikan dalam pelatihan; (a) komponen elektronika,

(b) simbol kelistrikan, (c) denah instalasi listrik rumah sederhana.

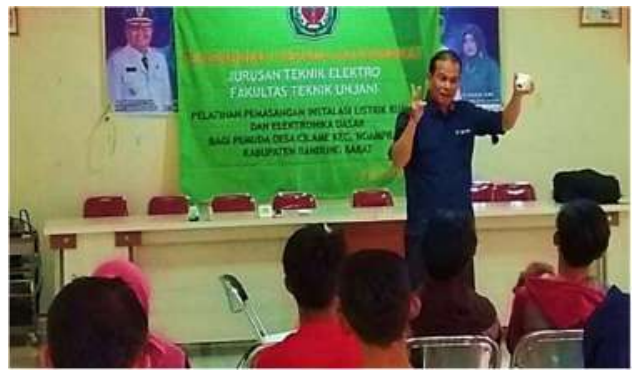

Gambar 3. Pemberian materi pelatihan
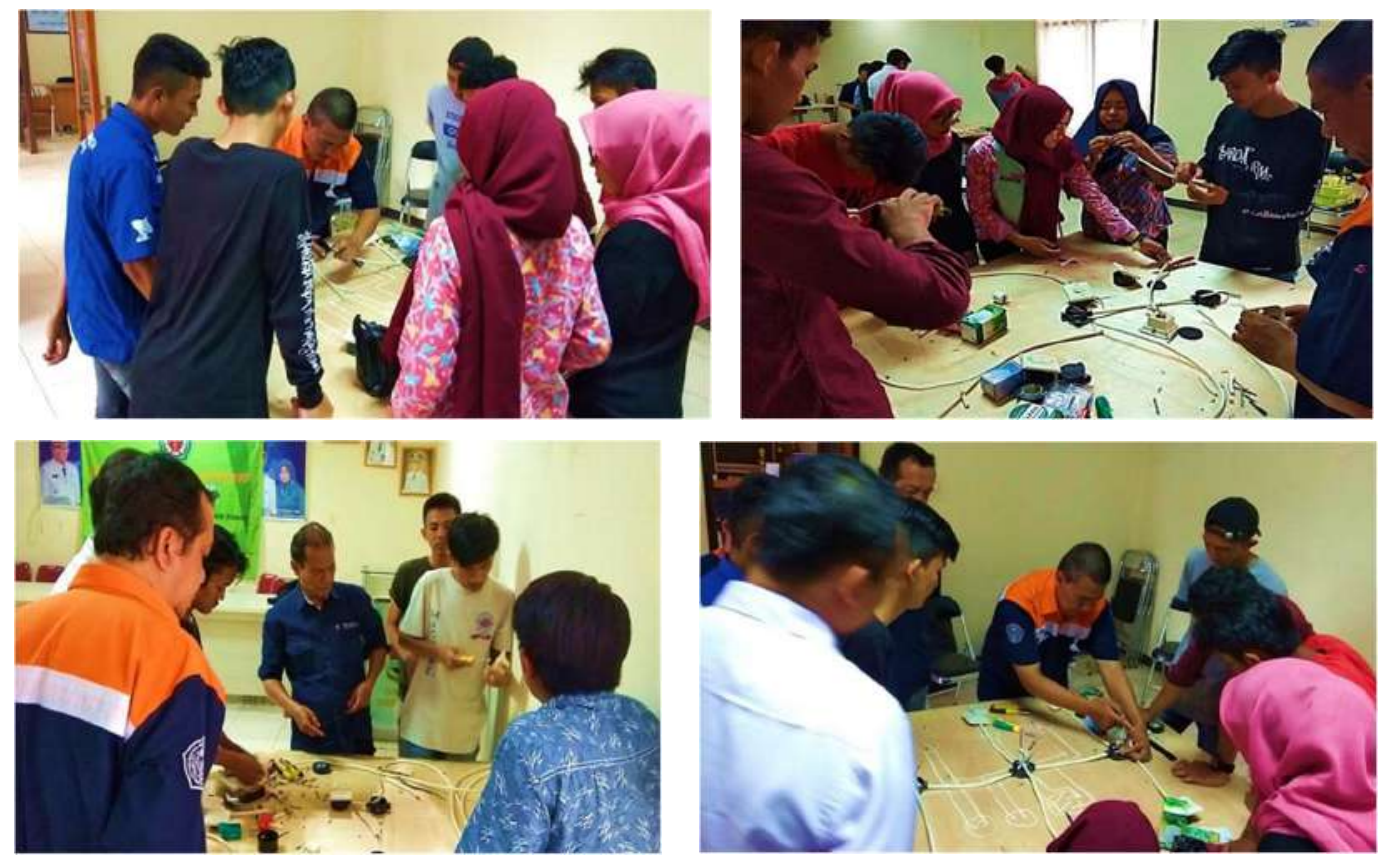

Volume 1, Nomor 1, Maret 2020| 16 Pelatihan Instalasi Listrik Rumah Tangga Dan Elektronika Dasar Bagi Pemuda Di Desa Cilame Kecamatan Ngamprah Kabupaten Bandung Barat Zul Fakhri, Sunubroto, Handoko Rusiana Iskandar, Ahmad Daelami https://doi.org/10.26874/jakw.v1i1.10 
Gambar 4. Praktik dibimbing oleh instruktur pelatihan

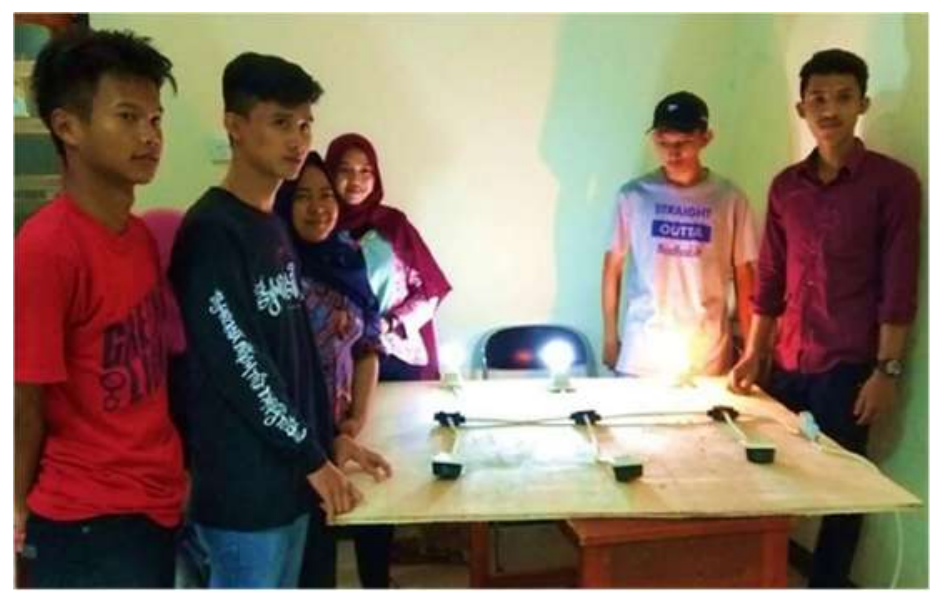

Gambar 5. Post-test peserta kegiatan pelatihan

Evaluasi terhadap hasil kegiatan pengabdian kepada masyarakat secara garis besar mencakup beberapa komponen sebagai berikut:
a) Keberhasilan target jumlah peserta pelatihan
b) Ketercapaian tujuan pelatihan
c) Ketercapaian target materi yang telah direncanakan.
d) Kemampuan peserta dalam penguasaan materi

Dari aspek target peserta pelatihan, jumlah peserta yang direncanakan berkisar antara 10-15 peserta. Dalam pelaksanaannya, kegiatan ini diikuti oleh 12 orang sehingga sesuai dengan yang direncanakan. Tingkat ketercapaian tujuan pembelajaran elektronika dasar dan pemasangan instalasi listrik rumah secara umum sudah baik, serta melakukan pengujian perangkat instalasi yang telah dibuat. Namun keterbatasan waktu yang disediakan mengakibatkan tidak semua materi tentang pengembangan media pembelajaran dapat disampaikan secara detil. Namun dilihat dari hasil latihan para peserta yaitu kualitas media pembelajaran yang telah dihasilkan, maka dapat disimpulkan bahwa tujuan kegiatan ini dapat tercapai.

Ketercapaian target materi pada kegiatan pengabdian kepada masyarakat ini cukup baik, karena materi pendampingan telah disampaikan secara keseluruhan. Materi pendampingan diberikan oleh instruktur yang berpengalaman dibidangnya dengan mengacu kepada standar nasional Indonesia dan metode pembelajaran yang menarik serta profesional.

Sementara itu, kemampuan peserta dari sisi penguasaan materi relatif baik. Namun 
demikian, tidak semua peserta dapat menguasai semua materi yang diberikan secara komprehensif. Hal ini disebabkan durasi pelatihan relatif singkat dan pemahaman dasar dari para peserta tidak sama. Selain itu, jumlah materi yang relatif banyak dalam waktu yang singkat tidak memungkinkan bagi para peserta untuk memahami dan mempraktikkan secara lengkap semua materi yang diberikan.

\section{Kesimpulan}

Kegiatan pengabdian kepada masyarakat berupa pelatihan instalasi listrik rumah tangga dan elekronika dasar telah diberikan kepada para pemuda di Desa Cilame Kecamatan Ngamprah Kabupaten Bandung Barat. Program pelatihan berjalan dengan baik dan lancar sesuai dengan rencana kegiatan yang telah disusun. Meskipun belum semua peserta menguasai dengan baik materi yang disampaikan, tetapi peserta antusias dalam mengikuti pelatihan yang diberikan dan terlibat aktif dalam sesi diskusi maupun praktik.

Beberapa saran tindak lanjut dari kegiatan pengabdian kepada masyarakat ini adalah sebagai berikut:

- Adanya kegiatan lanjutan yang berupa pelatihan sejenis yang diselenggarakan secara berkala sehinga dapat meningkatkan kemampuan peserta pelatihan.

- Penambahan waktu kegiatan yang masih kurang, sehingga harus diitambahkan jadwal dan waktu dalam kegiatan yang akan datang terutama memperbanyak aplikasi dari teori atau materi yang disampaikan oleh instruktur.

\section{Ucapan Terima Kasih}

Ucapan terima kasih disampaikan kepada para kolega dosen di Program Studi Teknik Elektro Universitas Jenderal Achmad Yani yang telah membantu pelaksanaan kegiatan pengabdian masyarakat di Desa Cilame Kecamatan Ngamprah Kabupaten Bandung Barat. Terima kasih juga disampaikan kepada LPPM Unjani yang telah mendanai kegiatan pengabdian masyarakat pada Tahun Anggaran 2018.

\section{Daftar Referensi}

Badan Pusat Statistik. 2018. Kecamatan Ngamprah Dalam Angka. Badan Pusat Statistik Bandung Barat, Bandung Barat. 
Hadiyati, E. 2011. Kreativitas dan Inovasi Berpengaruh Terhadap Kewirausahaan Usaha Kecil. Jurnal Manajemen Dan Kewirausahaan, 13(1), 8-16.

Hidayat, N., Arif, A., Setiawan, M.Y., Afnison, W. 2018. Peningkatan Pengetahuan dan Keterampilan Pemuda Putus Sekolah Melalui Pelatihan Perawatan Berkala Sepeda Motor. Jurnal Inovasi Vokasional dan Teknologi, 18(2), 83-89.

Nasrullah, A. dan Fatimah. 2017. Pembinaan Life Skill Anak Muda Putus Sekolah. Jurnal Dedikasi Masyarakat, 1(1), 23-30.

Resyaningrum, D. 2019. Bimbingan Karir Remaja Putus Sekolah Di Pusat Kegiatan Belajar Masyarakat (PKBM) Bunga Kantil Jebres Surakarta. Skripsi Jurusan Bimbingan dan Konseling Islam, Fakultas Ushuluddin dan Dakwah, Institut Agama Islam Negeri Surakarta, Surakarta.

Suranti, D., Maryaningsih, Mardianti, D. 2018. Pemberdayaan Pemuda Rentan Melalui Pelatihan Multimedia Di Kecamatan Sukaraja Kabupaten Seluma Provinsi Bengkulu. Jurnal Abdimas Dewantara, 1(2), 19-30. 